\title{
USE OF GREEN BUILDING INFORMATION MODELING IN THE ASSESSMENT OF NET ZERO ENERGY BUILDING DESIGN
}

\author{
Shang Yuan $\mathrm{CHEN}^{*}$ \\ School of Architecture, Feng Chia University, Taichung, Taiwan, R.O.C.
}

Received 23 June 2018; accepted 10 June 2019

\begin{abstract}
In the face of extreme climate, Net Zero Energy Buildings (NZEBs) represent a very high standard of building energy conservation. The design of NZEBs requires continuous design improvement and analysis in a decision-making process that seeks to meet energy conservation goals. This paper recommends the use of green Building Information Modelling (BIM) to support the design of zero-energy buildings. The design of NZEBs requires two sets of tasks: First, it requires determination of whether the building will offer high-energy efficiency, and, second, it lacks the installation of sufficient renewable energy equipment to meet the building's load needs. After drawing on the spirit of the United States' Leadership in Energy and Environmental Design and considering the current situation in Taiwan, this paper recommends the use of electricity Energy Usage Intensity as a measurement unit providing a holistic indicator of energy usage and takes optimized energy performance as a performance target for various solutions. This study demonstrated procedural steps in the application of green BIM and analyzed restrictions on the implementation of green BIM to the analysis of NZEB design.
\end{abstract}

Keywords: energy usage intensity (EUI), building information modeling (BIM), building performance analysis (BPA).

\section{Introduction}

In the face of extreme climate conditions, to maintain the sustainability and protect the earth's environment, the use of renewable energy is a rational solution to the problems of global warming, air pollution, and the need for energy security. Combining building energy conservation and use of renewable energy, the net-zero energy building (NZEB) concept represents an innovative means of achieving high energy performance buildings. In recent years, many countries, organizations, and associations have drafted numerous proposals and policies promoting NZEB research and demonstrations. The International Energy Agency's (IEA) Solar Heating and Cooling Program approved "Task 40: Towards Net Zero Energy Solar Buildings" (Task 40, 2017) as early as 2008, and the European Union (EU) has announced that energy conservation standards for new-construction buildings must comply with "nearly zero-energy building" guidelines starting in 2020 (European Commission, 2017). However, the United Kingdom (UK) has gone farther than the EU by announcing that all new-construction buildings must comply with zero carbon emission standards (Shrestha, 2016). The United States (US) Department of Energy's Net-Zero
Energy Commercial Building Initiative mandates that new-construction commercial buildings must meet zero energy consumption targets by 2025 (NetZero Energy Commercial Building Initiative, 2017). In Asia, Japan has set 2030 as the deadline for buildings to achieve zero carbon standards (Japan Zero Energy Buildings, 2017). Taiwan established the Zero Energy Building Technology Alliance (ZEBTA) in 2011 to promote NZEB development (Xie, 2011). In this context, what is an NZEB? What types of NZEBs are most suitable for one's own country? Do architects and designers have appropriate tools to achieve the ideals of NZEB design?

\section{Literature review}

Research on the NZEB concept has focused on: (1) Definition of the idea and summarization of its theoretical framework (Deng, Wang, \& Dai, 2014; Marszal et al., 2011; Sartori, Napolitano, \& Voss, 2012; Torcellini, Pless, \& Deru, 2006); (2) Case investigation and assessment (Desideri et al., 2014; Ascione, Bianco, Böttcher, Kaltenbrunner, \& Vanoli, 2016); (3) Practical use of energy conservation technologies (Mohamed, Cao, Hasan, \& Sirén, 2014); and (4) Integration of design and energy performance

${ }^{*}$ Corresponding author. E-mail: shangyuanc@gmail.com 
simulation and analysis tools and certification systems (Eleftheriadis, Mumovic, \& Greening, 2017; Ryu, Park, \& Rosen, 2016; Jalaei \& Jrade, 2015). In this paper, we construct an NZEB concept suitable for Taiwan through an examination of definitions, energy conservation indicators, energy efficiency, and performance targets:

\subsection{Definitions}

An NZEB must first be an energy-saving building. The energy consumption of a building as a whole can be offset by renewable energy generated on-site or obtained nearby so that a balance is achieved between energy consumption and energy output. To clarify the research subjects and technical boundaries involved in NZEB assessment, Deng et al. (2014) used a definition framework, equations, and graphics methods to describe the essential NZEB evaluation operating mechanisms, and proposed NZEB design elements, including energy-efficient measures, and their scope.

The most widely accepted definition of NZEB consists of a defined framework, which includes different elements. Different participants can, therefore, select different components based on individual considerations of cost, local climate, environmental protection demand, or the feasibility of on-site renewable energy sources, following a common framework, and thereby establish specific definitions of different applicable criteria. Basic NZEB evaluation operating mechanisms are as shown in Figure 1, where essential elements include the building system, energy grid, and weighting system. To perform the calculations needed to assess whether the net zero targets can be met, NZEB requires the delineation of boundaries around the building system's on-site renewable energy. Within these boundaries, when an on-site renewable energy power system generates excess power, the building system will transmit excess energy to the power grid. Besides, the net energy obtained by the building system as a whole will reflect the selected design goals and weighting system. For instance, when "kWh usage" is multiplied by "unit power price", we can obtain "cost of power", or when "kWh usage" is multiplied by the "power/carbon footprint coefficient", we can obtain $\mathrm{CO}_{2}$ emissions. Finally, the supply can be compared with the weighted load to determine whether net zero balance can be achieved via the specific technological solution.

Sartori et al. (2012) proposed a simplified equation to describe NZEB, which is shown in Equation (1). According to this equation, when the building boundaries are fixed, the balance of output and input energy during a specified period should be greater or equal to zero.

$$
\begin{aligned}
& \text { Net Energy }=\mid \text { output }|-| \text { input } \mid= \\
& \sum_{i} \text { Output energy }(i) \times \text { weight }(i)- \\
& \sum_{i} \text { Delivered energy }(i) \times \text { weight }(i) \geq 0 .
\end{aligned}
$$

First of all, an NZEB must be a high-energy conservation performance building. In Figure 2, the baseline value of the weighted demand on the $\mathrm{X}$-axis is the reference

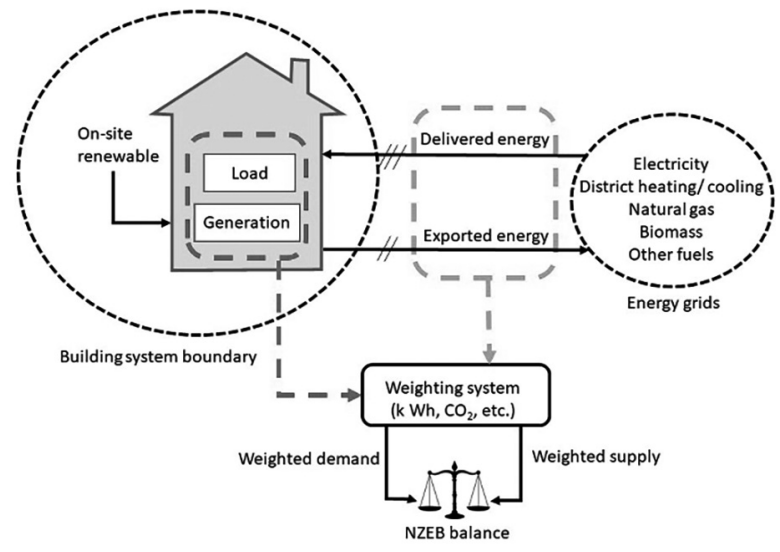

Figure 1. System structure and essential elements of NZEB

(Deng et al., 2014)

building value, which reflects basic energy conservation needs under local law. Here the possible reference building value refers to a representative value for a building of the same type and is used to make comparisons with the optimized design value. The higher the difference between the standard reference building value and the optimized design value, the higher the building's energy efficiency, which is equivalent to the concept of energy conservation performance in the NZEB framework. What is suitable energy efficiency? It will also be necessary to use highperformance energy conservation facilities and equipment to meet residents' need for comfort. Besides, the setting of optimal performance targets in NZEB design further requires to trade off the cost of renewable energy equipment and many other factors.

Consequently, we must shift our attention from the narrow definition of NZEB to a broader meaning. Based on the previous definition framework, equation, and graphic expression, the US Department of Energy has proposed the following four NZEB definitions and energy use classifications (Torcellini et al., 2006):

1) Net zero site energy consumption:

The on-site renewable energy generated by an NZEB should be greater than or equal to the energy used by that building for one year.

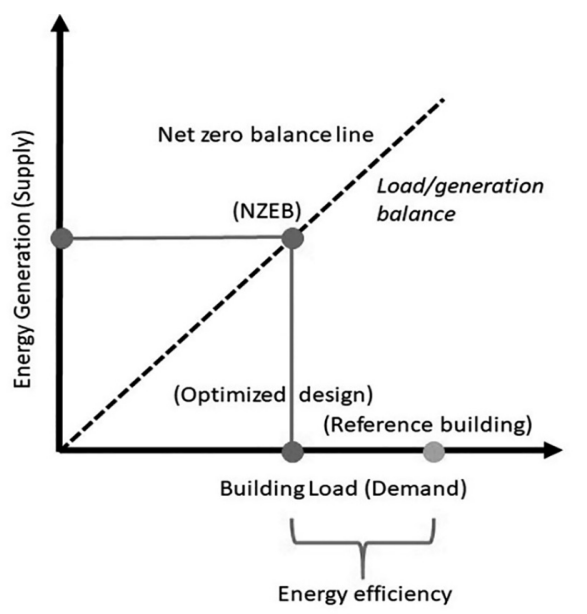

Figure 2. The Graphic expression of NZEB (Sartori et al., 2012) 


\section{2) Net zero source energy consumption:}

In terms of source, the renewable energy purchased or generated by an NZEB should be greater than or equal to the energy used by that building for one year.

3) Net zero energy costs:

In terms of cost, the income obtained from the sale of renewable energy generated by an NZEB to the local power company should greater than or equal to the cost of power purchased from the local power company during one year.

\section{4) Net zero emissions:}

In terms of greenhouse gas emissions, the renewable energy purchased or generated by an NZEB should be at least equivalent to the greenhouse gas emissions attributable to the building when using city power throughout one year.

First, an NZEB must be a high-energy conservation performance building, and then the purchase or generation of renewable energy is taken into consideration. As shown in Figure 3, calculation of the energy consumption of an NZEB as a whole should reflect three types of energy-efficient measures: (1) passive building design, (2) active service equipment and facilities, and (3) renewable energy generation systems.

To reduce energy load, an NZEB's passive design elements should include a suitable orientation, high-performance heat shield, excellent sealing, and window light shields, etc. Furthermore, to maintain the building's interior environment and resident comfort, the building must provide various active service equipment and facilities, such as heating, ventilation, and air conditioning (HVAC) system, domestic hot water (DHW) system, and lighting system. Because it is inevitable that these service systems will require various types of energy, such as natural gas or power, and renewable energy systems (such as an on-site photovoltaic system, wind power, water power, biomass energy, geothermal energy, and ocean energy systems, etc.) must be installed, or the building must obtain offsite renewable energy (such as energy from a community scale energy facility or green power provided by a public power plant, etc.) in order to offset its energy consumption. In short, the design of an NZEB will require ongoing

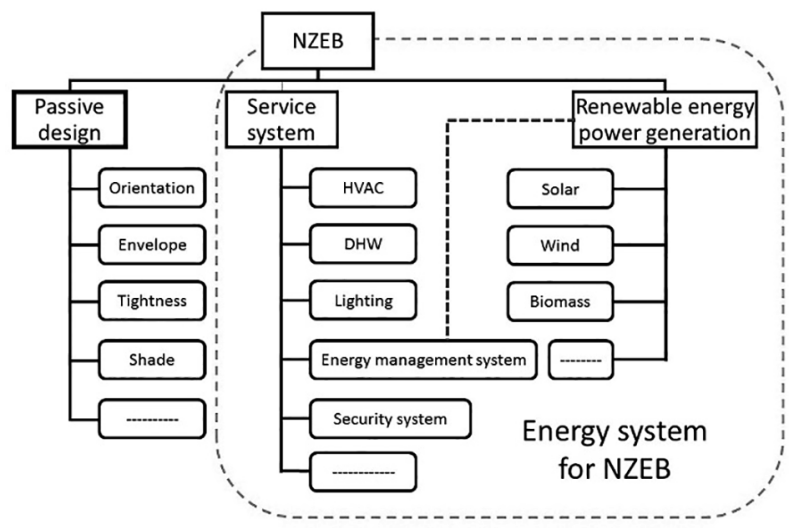

Figure 3. Design elements for NZEB (Deng et al., 2014) decision-making procedures involving a series of design improvements and analysis, until the energy conservation performance goals have been achieved. First, an NZEB must have an excellent passive architectural design, and employ high-efficiency active equipment and facilities, to reduce the building's energy load. Since the building must maintain occupants' health and comfort, optimized performance targets must be set reflecting such various factors as the cost of building materials, equipment, and facilities, and an optimal solution meeting the preset targets must be chosen. After this has been done, a renewable energy generation system or systems should be considered to offset the building's load.

\subsection{Energy conservation indicators, energy efficiency, and performance targets}

After reviewing NZEB operating mechanisms and energyefficient measures, it is also necessary to establish verification methods, including energy efficient authentication models, suitable for one's own country, and find appropriate design tools and operating modes to promote NZEB development effectively.

The energy efficiency of a green building can be graded utilizing a certification system's scoring scheme. However, a green building certified using common indicators will not necessarily have the requisite criteria of an NZEB. In order to protect the global environment and maintain sustainable development, various countries have established green building assessment systems appropriate for their domestic conditions (such as the United States' Leadership in Energy and Environmental Design (LEED) (LEED, 2017), the UK's Building Research Establishment Environmental Assessment Method (BREEAM) (BREEAM, 2017), China's assessment standards for Green Buildings (GB) (GB..., 2014), Japan's Comprehensive Assessment System for Building Environment Efficiency (CASBEE) (CASBEE, 2017), and Australia's Green Star (Green Star, 2017), etc.) Energy conservation indicators account for large shares of these green building assessment systems, and the systems rely on grading and verification employing their energy conservation indicators to compare the relative effectiveness of design proposals' energy-efficient measures. In this regard, Taiwan's architectural and construction industry has not lagged behind its peers. Taiwan's green building assessment system-Ecology, Energy Saving, Waste Reduction, Health (EEWH) (EEWH, 2017) - and Intelligent Building certification (Intelligent building, 2017) both provide quantitative scoring and grading methods for energy conservation indicators. These assessment and certification systems provide a reference basis for the energy conservation design work performed by designers and architects. However, as suggested by the problem points in Table 1, the daily energy efficiency indicators of Taiwan Green Building EEWH target focus on assessing the Building envelope heat load ratio, air conditioning efficiency, lighting energy efficiency ratio, etc., but failed to consider all the factors that affect the overall 
energy consumption of the building, that is, three types of energy-efficient measures. Besides, Taiwan's intelligent building energy conservation management indicators perform scoring based on the presence (with or without) and efficiency (excellent or bad) of relevant equipment and systems. The scoring does not have a positive correlation with energy consumption.

In contrast, the United States' LEED: Energy \& Atmosphere (EA) category (LEED: Energy and Atmosphere (EA) category, 2017) uses whole-building energy simulation software as in an integral part of the assessment, and the spirit of this approach is very consistent with the definition of an NZEB. Apart from some regulations and calculation units and weighting, this LEED category must be revised; however, in response to the actual conditions in different countries. LEED: EA first calculates whether design solutions meet the requirements of the American
Society of Heating, Refrigerating and Air-Conditioning Engineers (ASHRAE) 90.1 standards to establish baseline values. The design value of an optimal solution is then calculated, and the difference between the two values is used to calculate the optimized energy performance percentage. The solution can be assigned a score and grade based on this optimized energy performance percentage. (Table 2).

Given the current situation in Taiwan, this study recommends that the "Annual Electrical Power Consumption by Building Occupant per Unit Area" (2015) announced by Taiwan's Bureau of Energy, Ministry of Economic Affairs (Table 3) be taken as a source of reference NZEB baseline values. The performance targets that must be met by optimal solutions can be obtained from Equation (2), and are expressed as the percentage of optimized energy performance in units of Energy Use Intensity (EUI). For its part, LEED requires that the baseline

Table 1. Comparison of energy conservation indicators

\begin{tabular}{|c|c|c|c|}
\hline Indicator & $\begin{array}{c}\text { Taiwan's green building } \\
\text { EEWH daily energy conservation } \\
\text { indicators }\end{array}$ & $\begin{array}{l}\text { Taiwan's Intelligent Building } \\
\text { energy conservation management } \\
\text { indicators }\end{array}$ & $\begin{array}{c}\text { USA LEED } \\
\text { Energy \& Atmosphere }\end{array}$ \\
\hline Summary & $\begin{array}{l}\text { These indicators focus on the } \\
\text { assessment of Building envelope } \\
\text { thermal load ratio, air-conditioning } \\
\text { efficiency, and lighting energy } \\
\text { conservation ratio. Besides, a } \\
\text { particular reward coefficient } \\
\text { depending on the proportion of } \\
\text { renewable energy usage is provided } \\
\text { during the assessment to encourage } \\
\text { the application of renewable energy }\end{array}$ & $\begin{array}{l}\text { The content of the assessment focuses } \\
\text { on energy efficiency and energy } \\
\text { management. These indicators } \\
\text { chiefly address the use of power } \\
\text { by air-conditioning, lighting, and } \\
\text { power equipment in various types } \\
\text { of buildings, and assess the effect } \\
\text { of the adoption of high-efficiency } \\
\text { equipment, energy-saving technologies, } \\
\text { renewable energy equipment, and } \\
\text { energy monitoring and management. } \\
\text { This system also incorporates the } \\
\text { effectiveness of these functions in its } \\
\text { assessment }\end{array}$ & $\begin{array}{l}\text { Energy consumption is assessed } \\
\text { from a whole building perspective } \\
\text { to reduce energy consumption } \\
\text { through the assessment of energy } \\
\text { conservation design strategies and } \\
\text { the use of renewable energy }\end{array}$ \\
\hline $\begin{array}{l}\text { Constituent } \\
\text { factors }\end{array}$ & $\begin{array}{l}\text { 1. Calculation of Building envelope } \\
\text { load ratio } \frac{E V}{E V_{C}} \\
\text { 2. Calculation of air-conditioning } \\
\text { efficiency } \frac{A C}{A C_{C}} \\
\text { 3. Calculation of lighting energy } \\
\text { efficiency ratio } L_{\gamma} \\
\text { 4. Other: Air-conditioning \& } \\
\text { lighting power use ratio } \gamma, \text { Reward } \\
\text { coefficient: renewable energy ratio } \alpha \text {, } \\
\text { energy management efficiency } \beta\end{array}$ & $\begin{array}{l}\text { After the building has first been } \\
\text { determined to comply with necessary } \\
\text { regulations (mandatory, not scored), } \\
\text { incentive items (optional, scored), } \\
\text { which include the following, may be } \\
\text { selected: } \\
\text { 1. Energy management } \\
\text { 2. Equipment efficiency } \\
\text { 3. Energy conservation technology } \\
\text { 4. Renewable energy equipment }\end{array}$ & $\begin{array}{l}\text { First, concerning the required } \\
\text { criteria, it is determined whether } \\
\text { the solution complies with } \\
\text { ASHRAE } 90.1 \text { standards. Whole } \\
\text { building energy consumption } \\
\text { simulation is then performed using } \\
\text { software; the items considered } \\
\text { include: } \\
\text { 1. Passive building design } \\
\text { 2. Active service equipment and } \\
\text { facilities } \\
\text { 3. Renewable energy systems }\end{array}$ \\
\hline & Calculation formula & Expert review & Software calculation \\
\hline $\begin{array}{l}\text { Operating } \\
\text { methods }\end{array}$ & $\begin{array}{l}\text { Calculation of daily energy } \\
\text { conservation indicator } \\
\text { Estimation of the baseline value of } \\
\text { daily energy conservation indicators: } \\
E I=\left\{\left(\frac{E V}{E V_{C}}\right) \times\left(\frac{A C}{A C_{C}}\right) \times \gamma+L_{\gamma}\right\} \times \\
(1.0-\alpha-\beta) \\
E I_{C}=0.64 \times \gamma+0.9\end{array}$ & $\begin{array}{l}\text { Perform scoring first based on the } \\
\text { presence (Whether or not to adopt) } \\
\text { and the efficiency (excellent or bad) of } \\
\text { relevant equipment and systems }\end{array}$ & $\begin{array}{l}\text { Baseline value: Software is used } \\
\text { to calculate the baseline value of } \\
\text { a reference building. This value } \\
\text { is predicated on compliance with } \\
\text { ASHRAE } 90.1 \\
\text { Optimized design value: The next } \\
\text { step is to calculate the whole- } \\
\text { building energy consumption value } \\
\text { when various energy-efficient } \\
\text { measures are employed }\end{array}$ \\
\hline
\end{tabular}


End of Table 1

\begin{tabular}{|c|c|c|c|}
\hline Indicator & $\begin{array}{c}\text { Taiwan's green building } \\
\text { EEWH daily energy conservation } \\
\text { indicators }\end{array}$ & $\begin{array}{c}\text { Taiwan's Intelligent Building } \\
\text { energy conservation management } \\
\text { indicators }\end{array}$ & $\begin{array}{l}\text { USA LEED } \\
\text { Energy \& Atmosphere }\end{array}$ \\
\hline Results & $\begin{array}{l}\text { EI: Daily energy conservation } \\
\text { indicator } \\
E I_{C} \text { : Baseline daily energy } \\
\text { conservation indicator }\end{array}$ & $\begin{array}{l}\text { The total score will depend on } \\
\text { cumulative points from incentive items }\end{array}$ & \\
\hline $\begin{array}{l}\text { Verification } \\
\text { grading }\end{array}$ & If $\mathrm{EI}<E I_{C}$, the design is compliant & $\begin{array}{l}\text { Intelligent building grade depends on } \\
\text { the total score }\end{array}$ & $\begin{array}{l}\text { The solution is assigned a score } \\
\text { and grade based on the percentage } \\
\text { of optimized energy performance }\end{array}$ \\
\hline $\begin{array}{l}\text { Problem } \\
\text { points }\end{array}$ & $\begin{array}{l}\text { 1. The system only assesses key items } \\
\text { affecting daily energy consumption } \\
\text { and does not consider factors } \\
\text { affecting the overall energy } \\
\text { consumption of the building as a } \\
\text { whole } \\
\text { 2. The measurement units of building } \\
\text { envelope load, air-conditioning } \\
\text { efficiency, and lighting energy } \\
\text { conservation are inconsistent. } \\
\text { Unit-less ratios must, therefore, } \\
\text { be used in final calculations } \\
\text { to eliminate the discrepancies } \\
\text { between different units. However, } \\
\text { these ratios are not closely linked } \\
\text { with energy efficiency } \\
\text { Note: } \\
\text { Building envelope load, Building } \\
\text { envelope energy consumption: Units } \\
\text { of KWh/(m².a) } \\
\text { Air-conditioning efficiency (EER or } \\
\text { COP): Units of kcal/W or BTU/W } \\
\text { Luminous efficacy: Units of lm/W }\end{array}$ & $\begin{array}{l}\text { 1. Assessment of the relative efficiency } \\
\text { of equipment and systems by experts } \\
\text { may be affected by subjective factors } \\
\text { 2. Although the presence of } \\
\text { incentivized equipment and } \\
\text { functions will improve a proposal's } \\
\text { score, these items do not have a } \\
\text { positive correlation with energy } \\
\text { consumption and do not prove that } \\
\text { the design solution can conserve } \\
\text { energy }\end{array}$ & $\begin{array}{l}\text { 1. The software must be tested } \\
\text { and certified by a credible } \\
\text { certification organization. } \\
\text { Nevertheless, not all countries } \\
\text { can consequently establish such } \\
\text { software and organization. The } \\
\text { software must meet ASHRAE } \\
\text { standards and obtain ANSI/ } \\
\text { ASHRAE Standard } 140 \text { testing } \\
\text { and certification in the United } \\
\text { States (Emilekfouri, 2013) } \\
\text { 2. Different countries use } \\
\text { different units and weighting } \\
\text { when calculating energy } \\
\text { consumption. In the case of the } \\
\text { US, a building's annual energy } \\
\text { consumption and petrochemical } \\
\text { energy consumption are } \\
\text { typically used to calculate total } \\
\text { energy consumption, which is in } \\
\text { source EUI units of Btu/ft }{ }^{2} \cdot y r .\end{array}$ \\
\hline
\end{tabular}

values of solutions be calculated following the standards in ASHRAE 90.1. To ensure applicability to local conditions, an assessment system must comply with the local energy code and architectural technologies (Gurgun, Polat, Damci, \& Bayhan, 2016). In general, building energy assessment typically EUI as an indicator. EUI is defined as a building's annual energy consumption divided by the building's total floor area. Unlike LEED's definition, the definition of EUI in Taiwan consists solely of a building's annual electricity consumption during its operating period. In Taiwan, electricity EUI consequently has

Table 2. LEED grading and scoring of the percentage of optimized energy performance (LEED: Optimize energy performance, 2017)

\begin{tabular}{|c|c|c|}
\hline New construction & Major renovation & Points \\
\hline $6 \%$ & $4 \%$ & 1 \\
\hline $8 \%$ & $6 \%$ & 2 \\
\hline $10 \%$ & $8 \%$ & 3 \\
\hline $12 \%$ & $10 \%$ & 4 \\
\hline $14 \%$ & $12 \%$ & 5 \\
\hline $16 \%$ & $14 \%$ & 6 \\
\hline $18 \%$ & $16 \%$ & 7 \\
\hline
\end{tabular}

units of $\mathrm{kWh} / \mathrm{m}^{2}$.yr. Furthermore, to facilitate peer group comparison, the Bureau of Energy, Ministry of Economic Affairs has issued the Comparison of Power Consumption per Unit Area for Different Types of Building Users. This table provides power consumption statistics per unit area including or not including indoor parking facilities, and can enable energy management personnel to perform energy conservation self-assessments and evaluate energy conservation improvement targets.

\section{Theory and methods: use of green BIM as a tool for NZEB integrated design and analysis decision-making procedures}

Based on the above, the design of NZEBs requires continuous design improvement and analysis in a decisionmaking process that seeks to meet energy conservation performance goals. Green building information modeling (BIM) emphasizes the integration of BIM and Building Performance Analysis (BPA) software and employs an integrated design decision-making cycle consisting of building design and analysis to achieve optimized development providing greater environmental effectiveness.

BIM and BPA were initially separate types of software, but have been increasingly integrated with the response to users' needs. BIM is based on 3-D modeling, which 
Table 3. Annual Electrical Power Consumption by Building Occupant per Unit Area, 2015

\begin{tabular}{|c|c|c|c|c|}
\hline \multicolumn{2}{|c|}{ Building user types } & \multicolumn{3}{|c|}{$\begin{array}{l}\text { Annual power consumption per unit area, } \\
\text { not including indoor parking facilities }\left(\mathrm{kWh} / \mathrm{m}^{2} \cdot \mathrm{yr}\right)\end{array}$} \\
\hline Major category & Subcategory & Average value & Minimum value & Maximum value \\
\hline \multirow{2}{*}{ Government agencies } & Central (general administration) & 124.8 & 33.0 & 219.3 \\
\hline & Local (general administration) & 110.0 & 46.8 & 183.2 \\
\hline \multirow{4}{*}{ School } & General University & 80.2 & 37.3 & 130.7 \\
\hline & University of technology & 74.4 & 42.3 & 149.3 \\
\hline & High school & 59.1 & 21.6 & 98.7 \\
\hline & Business/technical school & 66.2 & 22.4 & 118.2 \\
\hline Office towers & & 163.1 & 95.4 & 289.5 \\
\hline \multirow{3}{*}{ Hotels } & International tourist hotel & 230.5 & 103.6 & 642.7 \\
\hline & General tourist hotel & 224.6 & 72.6 & 418.6 \\
\hline & General hotel & 239.2 & 44.3 & 397.0 \\
\hline
\end{tabular}

The percentage of optimized energy performance $=\frac{\left(E U I_{b}-E U I_{d}\right)}{E U I_{b}} \times 100 \%$.

supersedes an older communication model consisting of chiefly 2 -D drawings. BIM can greatly decrease information transmission errors, and can also lessen construction and operational management risk and cost. BIM has two underlying functions: One is information modeling, and the other is information management. The BIM employs both geometric and non-geometric information in whole building life cycle modeling processes (Eastman, 2008).

BPA, which is also known as Building Performance simulation (BPS), involves the use of computer software to predict building performance. BPA software can output visualized simulation drawings, data, statistical analysis graphics, and tables; it can help users to understand the performance of their design solutions, facilitating design decision-making and providing a basis for continuing optimization of a design solution. Because of the complexity of building energy consumption prediction, energy simulation tools are typically composed of two parts: The first part consists of the engine, which includes formulas and procedures; the second part consists of the user interface, which facilitates the input of parametric data and display of results. Most simulation engines have been developed at academic institutions or research organizations, while the user interfaces have mostly been developed and realized at private software companies. These engines and user interfaces are combined in the wide array of BPA software available on the market (such as RIUSKA, eQUEST, and DesignBuilder, etc.) (Maile, Fischer, \& Bazjanac, 2007) (Figure 4).

As of July 2017, the US Department of Energy's building energy software tool website contained 59 whole building energy performance simulation tools (Building Energy Software Tools, 2017). However, most of BPA and BIM software solutions were separate, interoperation between the two and interconversion of their different formats were problematic (Østergård, Jensen, \& Maagaardb, 2016). By combining BIM modeling with the performance simulation functions of its Green Building Studio (GBS), Autodesk has overcome the limitations of existing BPA software with third-party user interfaces and enables an integrated design and analysis decision-making cycle. The Autodesk Revit platform relies on Autodesk's cloud GBS to transmit information created or input on the Revit platform, including (1) building geometric information (configuration, shape, and orientation), (2) geographic and weather data (geographic coordinates, environmental characteristics, temperature, humidity, path of the sun, and wind rose, etc.), and (3) non-geometric attributes and parameters (spatial categories, wall structures, thermal conduction performance, active equipment options, operating plans, and parameter settings), in the gbXML format to GBS' DOE-2 energy simulation engine in the cloud. After computation, results are transmitted back to the Revit platform for display (Green Building Studio, 2017) (Figure 5). The green BIM integrated platform enables the energy consumption calculation and design of an NZEB as a whole, reflecting three types of energy-efficient measures.

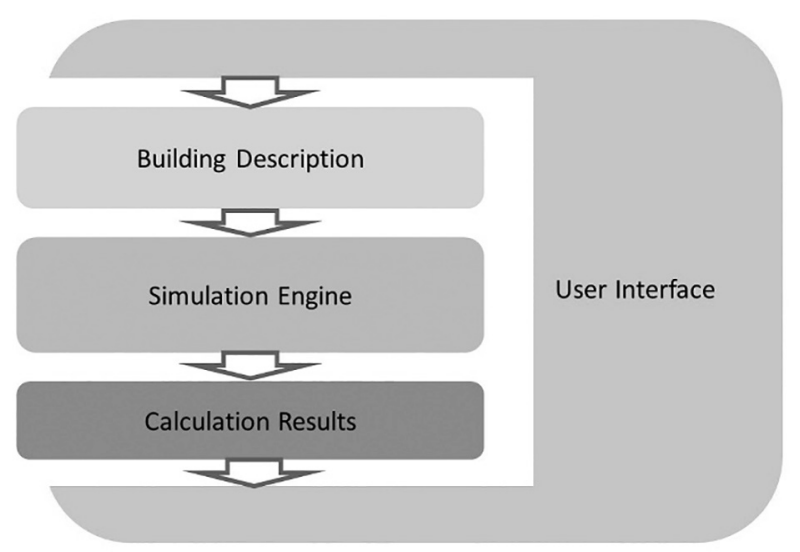

Figure 4. The general architecture of a building performance simulation tool (Maile et al., 2007) 


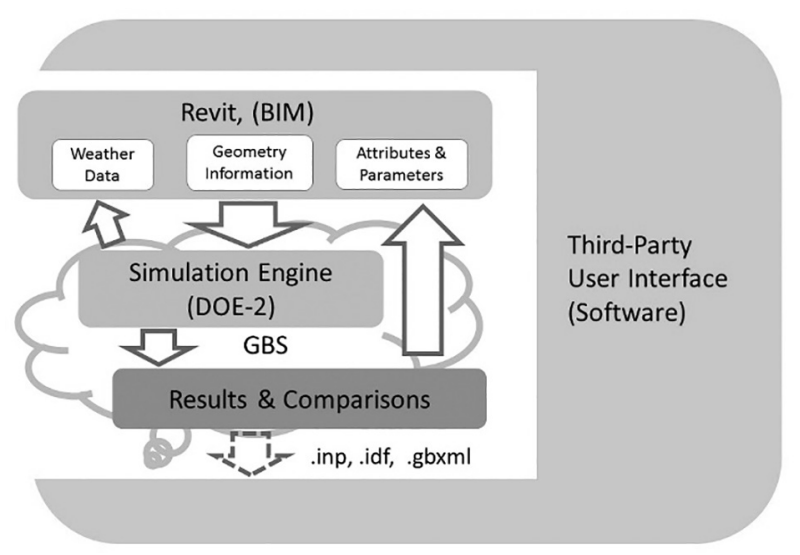

Figure 5. The architecture of Revit \& Energy Analysis for Revit

\section{Realization and verification}

Green BIM used as an NZEB integrated design and analysis decision-making tool emphasizes the use of BIM as an essential tool from the start of the design process. Responding to localized climate conditions, BPA was implemented via a decision-making cycle consisting of design and analysis steps, and continued design optimization performed to obtain an optimal proposal meeting the need for environmental effectiveness, which ultimately achieved the goal of environmental sustainability. Figure 6 shows the intersection of BPA with BIM and sustainable design. Implementation of BPA tasks begins during an early sustainable design stage (typically during the schematic design and design development stage) (Andrasik, 2015). An NZEB must first be an energy-saving building. The energy consumption of a building as a whole can be offset by renewable energy generated on-site or obtained nearby so that a balance is achieved between energy consumption and energy output.

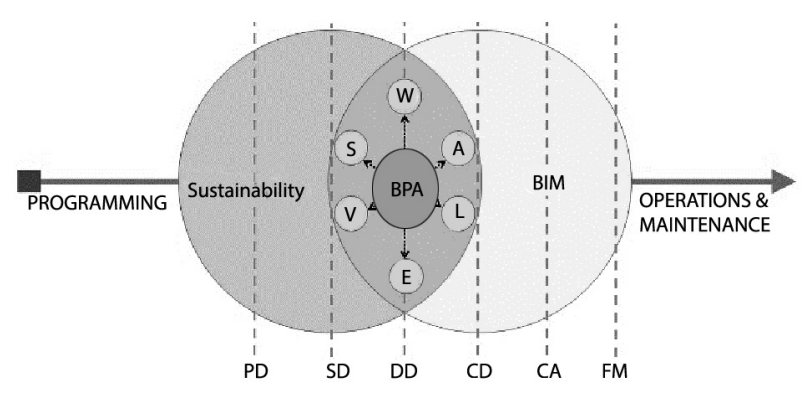

Note: PD: pre-design, SD: schematic design, DD: design development, CD: construction detailing, CA: construction administration, FM: facility management, W: Water resource analysis, A: Acoustics performance analysis, L: Lighting \& Daylighting analysis, E: Energy performance analysis, V: Visual impact analysis, S: Sun \& Shadow analysis.

Figure 6. The linkage between sustainable design, BPA, and BIM (Andrasik, 2015)

\subsection{Stage 1: determine whether the building is energy efficient}

Stage 1 includes SD to DD. SD covers steps (1)-(8), and DD covers steps (4)-(8). Whether it is SD or DD, the optimization of the design is a process of continually improving the solutions until to meet the set target. Sometimes the goal is easy to achieve, and maybe the first design has already met.

Nevertheless, sometimes the target is not easy to reach, and we must continuously try out possible design options. Even if the target is impossible to achieve, or if we have to pay too high a price for it, we need to go back and fix the set target. As far as the general knowledge of architecture is concerned, the building massing and configuration are more influencing building energy consumption than other parameters. Therefore, in the SD phase, consider regional climatic conditions (especially the sunshine trajectory and seasonal wind direction), under the principle of passive architecture, designers need to do multiple designs for building's massing and configuration and then select the optimal one to make DD and further adjustment of other parameters.

This study employed BPA and design optimization for a new-construction hotel in Taichung to apply and verify a green BIM decision-making cycle. In consideration of BIM and BPA software compatibility, this study employed Autodesk Revit as a BIM and BPA integrated platform. The steps shown in Figure 7 were used to perform energy consumption analysis, and their details and demonstrations are as follows:

1) Delineation of the scope of the discussion of the project within the building life cycle:

Green BIM focused on the decision-making cycle from the Schematic Design (SD) to the Design Development (DD) stage. The first task was to find candidate optimal solutions with different conceptual mass configurations during the SD stage based on the pre-set target for optimized energy performance. Steps (4)-(7) implemented repeatedly, until an optimal solution had been selected, after which the process entered the DD stage. Steps (4)(8) were executed repeatedly while particular building elements were added, and elements' attributes and parameters were adjusted to ensure the continuous optimization of performance (Figure 8).

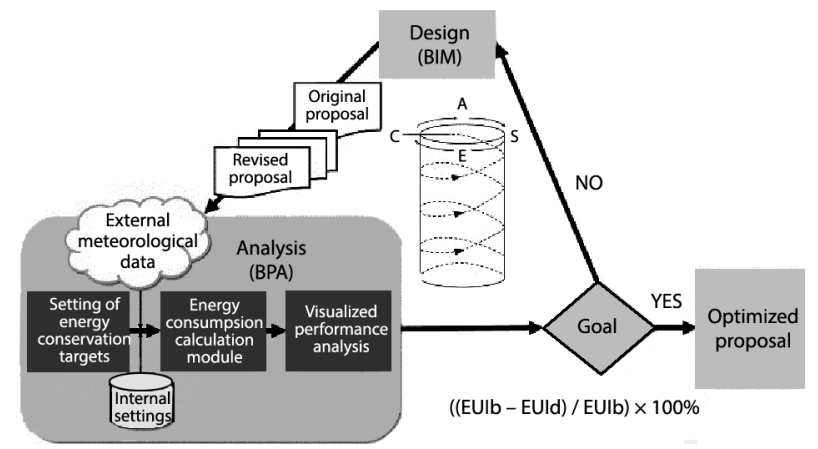

Figure 7. Stage 1 of integrated green BIM design procedures 


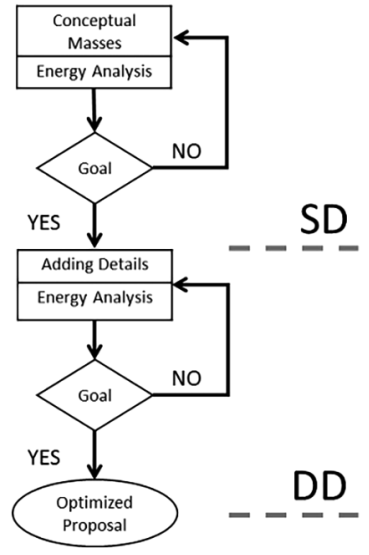

Figure 8 . The performance analysis and optimized design decision-making cycle (SD-DD)

- In Schematic Design (SD)

2) The setting of energy conservation performance targets:

For example, the energy conservation targets set for the SD stage in this project was optimized energy performance at least $28 \%$ better than the baseline solution, and at least a $5 \%$ improvement during the DD stage. This study recommends that electricity EUI is used as a holistic indicator for building energy consumption. Besides, the average values in the Comparative Table of Power Consumption per Unit Area for Different Types of Building Users (Table 3) issued by the Taiwan Bureau of Energy, Ministry of Economic Affairs were taken as reference NZEB baseline values, which is not including indoor parking facilities. The case project was positioned as a "general tourist hotel", and had a baseline electricity EUI value of $224.6 \mathrm{kWh} / \mathrm{m}^{2}$.yr. The difference between the baseline project's EUI value (EUIb) and the optimized project's EUI value (EUId) was used to obtain the ratio of EUId to EUIb, and the resulting optimized energy performance was then used as a performance target and grading criterion. Equation (2)

3) Accessing external meteorological data:

The project site was located in the Beitun District of Taichung. After inputting the geographic coordinates of the project site, Revit received Typical Meteorological Year (TMY) weather data for the nearest weather station from Green Building Studio (GBS) (Malkin, 2008) (Figure 9).

4) Entering internal settings:

The designer first established an initial solution (Create Mass/Place Mass) (Figure 10), which was created using geometric information through a simple modeling process, and consisted of a mass and floors. Besides, subsequently set up non-geometric information in the energy setting, included a building typesetting of "hotel building" and an initial percentage glazing setting of $40 \%$. The building operating details referred to the weekly hours the building would be in use, where 12/7 indicated that the building would in use for seven days each week, and would operate for 12 hours each day. The HVAC system referred to the electrical air conditioning system settings, where default

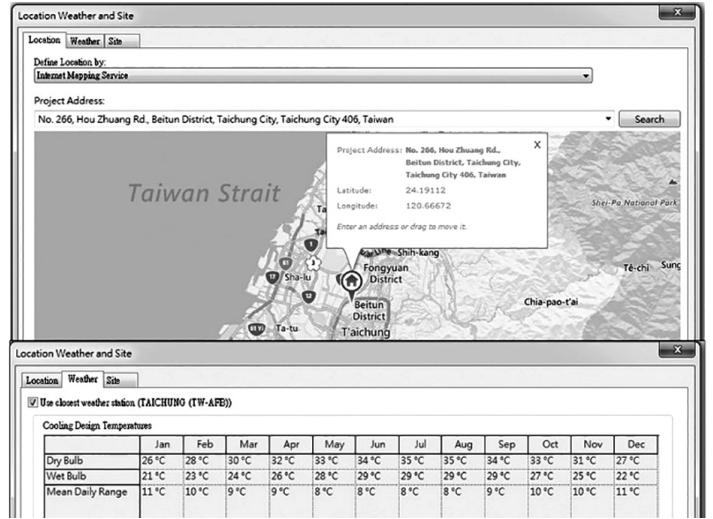

Figure 9. Site location settings TMY weather data

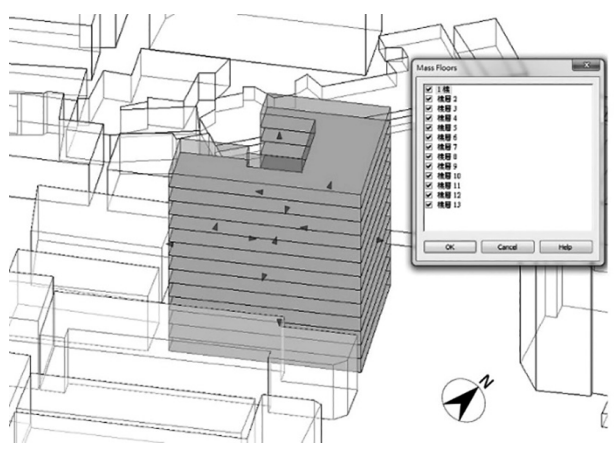

Figure 10. Creation of a mass model with floors (geometric information)

settings were central VAV, water heating, a 5.96 Coefficient of Performance (COP), standards for chiller capacity, and boiler with an efficiency of 84.5. The external air volume setting- referred to the amount of external air needed by each person, the air exchange required per unit area, and the hourly ventilation rate. Default values (Table 4) were used for other settings, such as the structural materials. After all, settings have been completed, Revit converted the data to an energy analysis model (Figure 11).

Table 4. Internal building settings: attributes and parameters

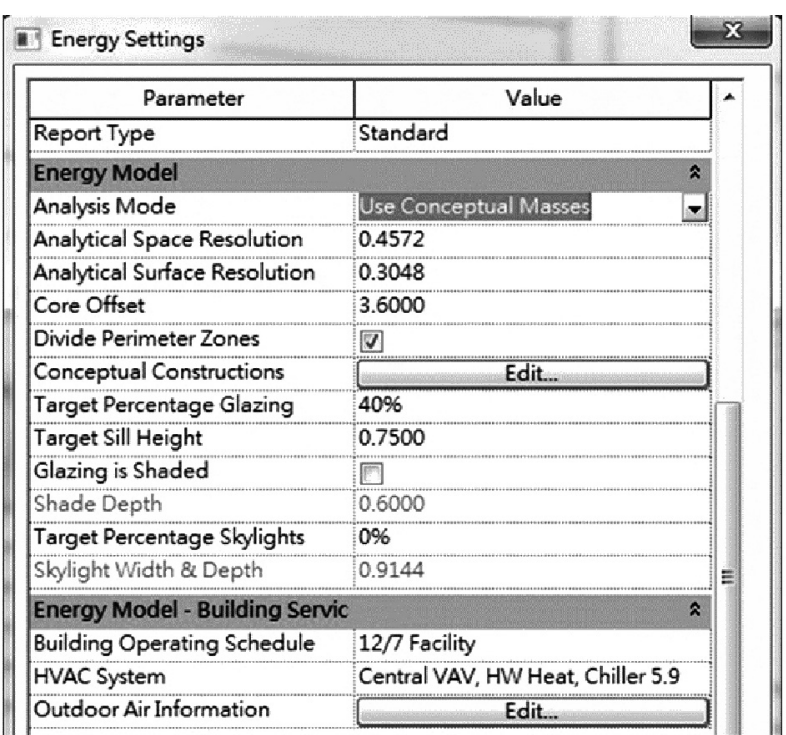




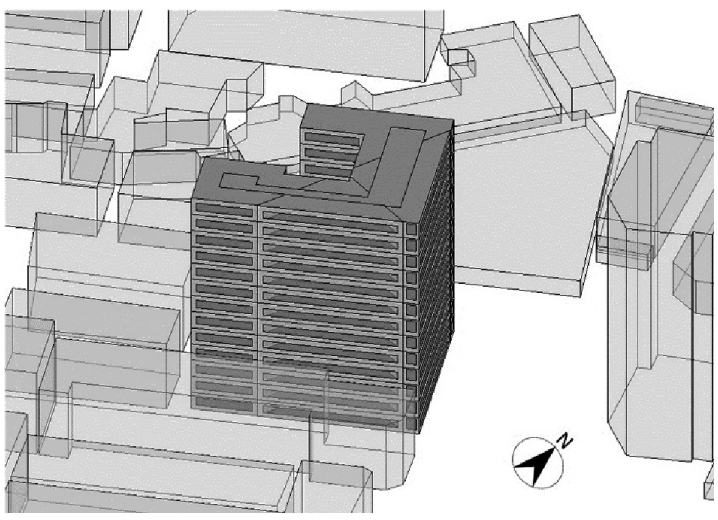

Figure 11. Conversion to an energy analysis model

5) Running the energy conservation calculation module:

As shown in Figure 5, Revit and Energy Analysis for Revit uniformly transmit the model's geometric information, non-geometric internal settings (performance parameters) and weather data to GBS in the gbXML format, where the Department of Energy-2 (DOE-2) engine performs energy consumption analysis.

6) Visualization and hotspot tracking:

Visualization: After the Doe-2 simulation engine performs computation on the cloud, GBS transmitted the visualized building performance values. These items include (1) site weather analysis and (2) building energy use and load performance analysis. This information was presented as simulated graphics, various types of numerical analysis tables, and statistical figures and charts. Analysis of site weather conditions included the creation of a wind rose, which indicated wind directions, wind speed, and frequency of occurrence for each month (Figure 12).

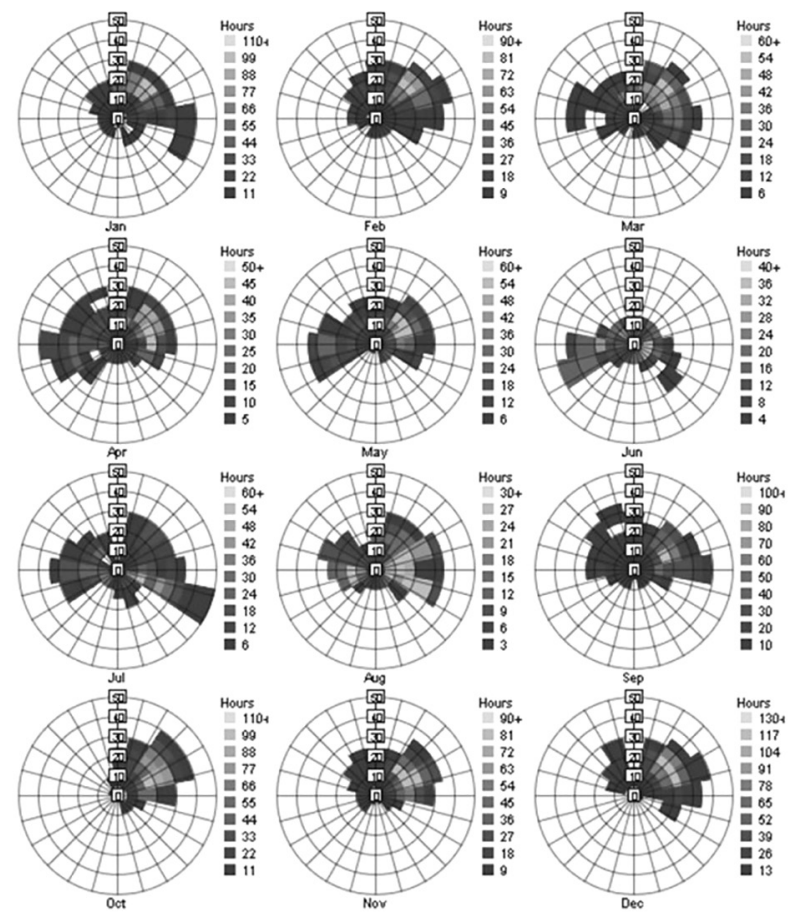

Figure 12. Wind rose
Building energy use and load performance analysis includes EUI, building life cycle (30 years) energy consumption and cost calculations, energy recovery/energy conservation potential, average carbon emissions, monthly air-conditioning load, and peak power demand. Users can review this information and performance calculation results in reference to target settings, and can subsequently revise the solution based on key factors.

Hotspot tracking: Following visualization results, users can judge which variables have a significant influence on energy consumption at an early date, allowing them to revise the solution subsequently.

In the case of the US, a building's annual energy consumption and petrochemical energy consumption are typically used to calculate total energy consumption, including electricity, natural gas, geothermal, etc., which is in source EUI, unit of $\mathrm{Btu} / \mathrm{ft}^{2} \cdot \mathrm{yr}$. The software used in this paper will show the calculation of total energy consumption after running the energy conservation calculation module. However, Taiwan only has electricity EUI statistics on the power of various buildings and uses electricity as its main demand for energy-saving measures. Therefore, the EUI calculations in this paper emphasize the use of electricity EUI, units of $\mathrm{kWh} / \mathrm{m}^{2} \cdot \mathrm{yr}$.

The initial solution in this study had a EUI of $204 \mathrm{kWh} / \mathrm{m}^{2} \cdot \mathrm{yr}$., which was less than general baseline value of $224.6 \mathrm{kWh} / \mathrm{m}^{2}$.yr.; the building's optimized energy performance was calculated to be $9.17 \%$, which was less than the pre-set target value of $28 \%$ (Table 5). The building's passive design was found to be heavily influenced by the seasonal monsoon winds, which blow from the southwest at this site in the summer and from the northeast in the winter. By leaving open space in the site, the building tends to face the wind in the summertime but is protected from the wind in the winter. The modeling results showed that this configuration left room for further improvement (Figure 13). Based on the analysis

Table 5. Summary of the results of the analysis

\begin{tabular}{|l|l|}
\hline \multicolumn{2}{|l|}{ Building Performance factors } \\
\hline Location: & T'aichung, Taiwan \\
\hline Weather Station: & 548644 \\
\hline Outdoor Temperature: & Max: $35^{\circ} \mathrm{C} / \mathrm{Min} 8^{\circ} \mathrm{C}$ \\
\hline Floor Area: & $8298 \mathrm{~m}^{2}$ \\
\hline Exterior Wall Area: & $5840 \mathrm{~m}^{2}$ \\
\hline Average Lighting Power: & $9.69 \mathrm{~W} / \mathrm{m}^{2}$ \\
\hline People: & $332 \mathrm{people}$ \\
\hline Exterior Window Ratio: & 0.40 \\
\hline Electrical Cost: & $\$ 0.06 / \mathrm{kWh}$ \\
\hline Fuel Cost: & $\$ 1.20 / \mathrm{Therm}$ \\
\hline Energy Use Intensity & \\
\hline Electricity EUI: & $204 \mathrm{kWh} / \mathrm{sm} / \mathrm{yr}$ \\
\hline Fuel EUI: & $42 \mathrm{MJ} / \mathrm{sm} / \mathrm{yr}$ \\
\hline Total EUI: & $778 \mathrm{MJ} / \mathrm{sm} / \mathrm{yr}$ \\
\hline
\end{tabular}




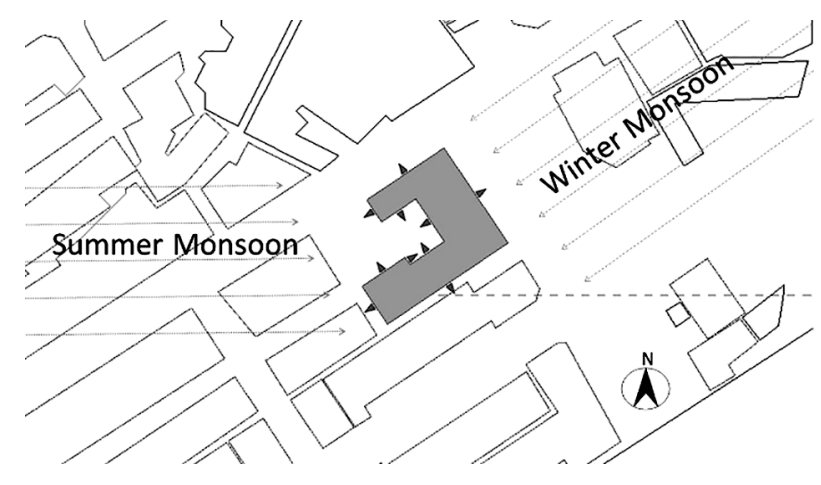

Figure 13. The schematic diagram of seasonal winds and building configuration

of proportional power consumption by various equipment, it was found that air conditioning used the most power (46\%), followed by lighting (21\%) (Figure 14). Review of monthly energy load: Energy load composition analysis indicated that sunlight and heat conduction through windows was the largest source of air conditioning load, followed by lighting equipment and solar radiation through open windows. Concerning the monthly distribution of power consumption, power usage was highest during the summer months of July and August (Figure 15). This phenomenon indicates that reducing summertime power consumption will reduce building operating costs.

\section{7) Revised solution:}

Following the wind rose and results of hotspot tracking, this study reviewed the relationship between the building mass and outdoor space during the SD stage to obtain a revised solution. The study repeatedly implemented steps (4)-(7) and performed the assessment. This process resulted in candidate optimal solution $\mathrm{D}$, which was able to meet the energy conservation performance target (Figure 16).

8) Optimal solution:

Candidate optimal solution D had EUI $=153 \mathrm{kWh} /$ $\mathrm{m}^{2}$.yr., which was $71.6 \mathrm{kWh} / \mathrm{m}^{2}$.yr. less than the baseline EUI $=224.6 \mathrm{kWh} / \mathrm{m}^{2} \cdot \mathrm{yr}$., and optimized energy performance of $31.87 \%$. This result met the SD stage goal of energy performance at least $28 \%$ better than the baseline EUI value.

- In Design development stage (DD)

We can see from the preceding analysis that after taking the conceptual mass of candidate optimal solution D during the schematic design (SD) stage, Revit modeling was performed again during the design development (DD) stage, including repeated implementation of Green BIM steps (4)-(8). However, the analytical mode in step (4) was changed to "Use building elements". The following is a further explanation of steps (7) and (8) in the DD stage:

9) Revised solution:

A monthly energy load review after revision in response to results of hot spot tracking found that heat

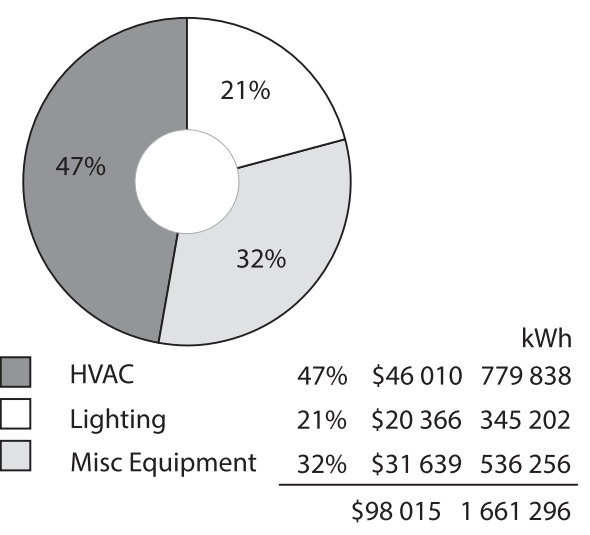

Figure 14. Analysis of proportional power use

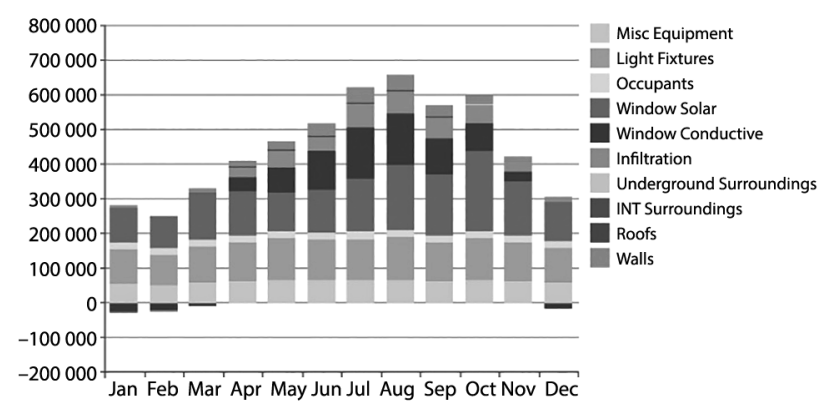

Figure 15. Summary of monthly energy load

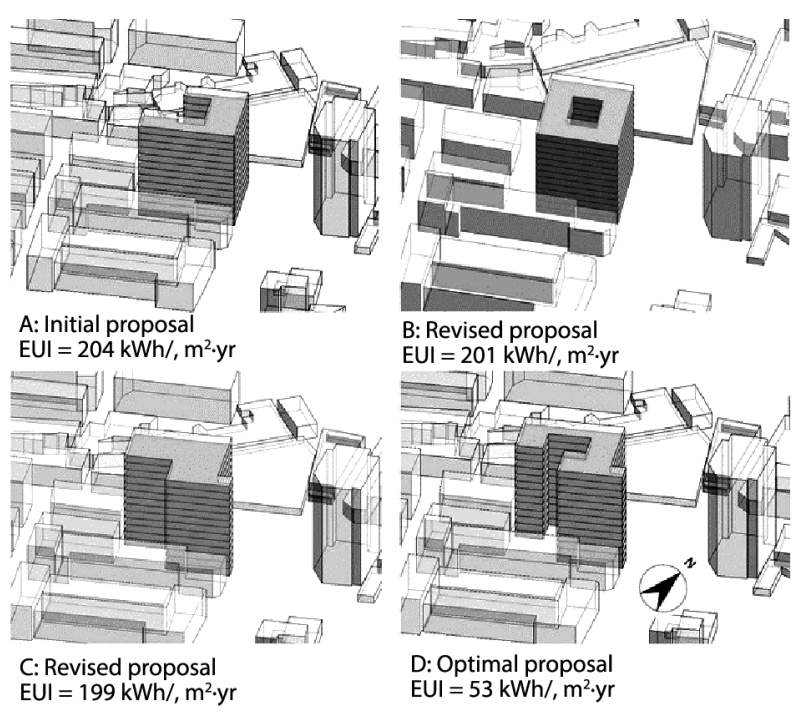

Figure 16. Continuing optimizing solutions

conduction through the windows, and outer walls were the largest source of air conditioning load. While the study formerly employed a $40 \%$ glazing, this was revised and reduced to $29 \%$ after the addition and revision of window elements (Figure 17). Besides, the outer walls were set as thermally insulated walls, windows were set as having two-layer Low-E glass, horizontal shading eaves were placed on the southern and northern facades, and vertical shading eaves were placed on the eastern and western facades (Figure 18). 


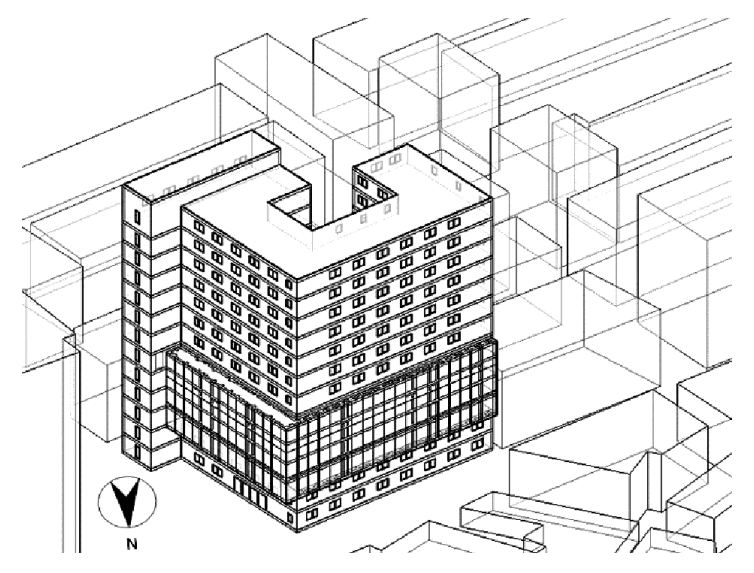

Figure 17. Addition of window elements, insulating walls, and Low E glass

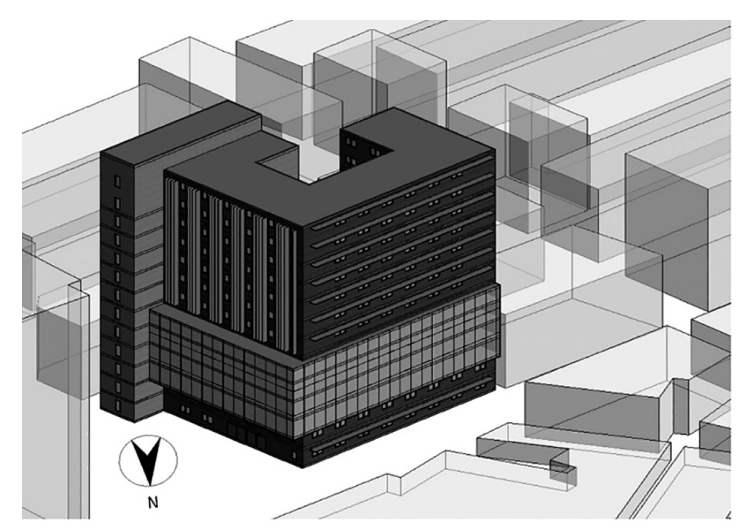

Figure 18. Addition of shades

\section{0) Optimal solution:}

In the DD stage, the EUI value of candidate optimal solution D was improved to $140 \mathrm{kWh} / \mathrm{m}^{2}$ yr., which was a reduction of $13 \mathrm{kWh} / \mathrm{m}^{2} \mathrm{yr}$. compared with the EUI of $153 \mathrm{kWh} / \mathrm{m}^{2} \mathrm{yr}$. of the conceptual mastering the SD stage. With an optimized energy performance of $8.5 \%$, candidate optimal solution D met the target of 5\% performance improvement compared with the SD stage (Table 6).
Table 6. Best optimal solution (DD)

\begin{tabular}{|l|l|}
\hline \multicolumn{2}{|l|}{ Energy Use Intensity } \\
\hline Electricity EUI: & $140 \mathrm{kWh} / \mathrm{sm} / \mathrm{yr}$ \\
\hline Fuel EUI: & $132 \mathrm{MJ} / \mathrm{sm} / \mathrm{yr}$ \\
\hline Total EUI: & $636 \mathrm{MJ} / \mathrm{sm} / \mathrm{yr}$ \\
\hline
\end{tabular}

\subsection{Stage 2: installing sufficient renewable energy equipment}

After selecting the best optimal solution from stage 1, it takes into account the scale and construction of all renewable energy equipment and facilities and calculates the renewable energy they can provide throughout the year. However, limited to the software used in this study, only the solar analysis module is currently available. Therefore, this paper only designs and calculates solar energy by its analysis module, including four steps. The solar panel analysis module was used to predict part of the building's power supply. The steps are as follows:

1) Using the Solar Analysis module:

The scope of the selected solar panel coverage was as shown in light blue in Figure 19. After making this selection and updating the screen, the covered area was calculated to be $1264 \mathrm{~m}^{2}$.

2) Filling out the settings form:

The main parameters included the building's usable area $\left(8600 \mathrm{~m}^{2}\right)$, EUI $\left(140 \mathrm{kWh} / \mathrm{m}^{2} \mathrm{yr}\right.$.), the price of power (NT\$ $3.5 / \mathrm{kWh}$, and the selected solar panel type $(20.4 \%$ $\$ 3.47$ / installed Watt).

3) Implementing Solar Analysis calculations:

The system displayed the solar power output (216 $785 \mathrm{kWh} /$ year) and the power cost savings (NT\$758 748/year). Given the building's annual power consumption (1 $204000 \mathrm{kWH} /$ year), the selected solar panel coverage would provide $18 \%$ of the building's annual power needs.

4) Consideration of other renewable energy equipment:

Other renewable energy equipment can be used to supply the remaining $82 \%$ of the building's power usage,

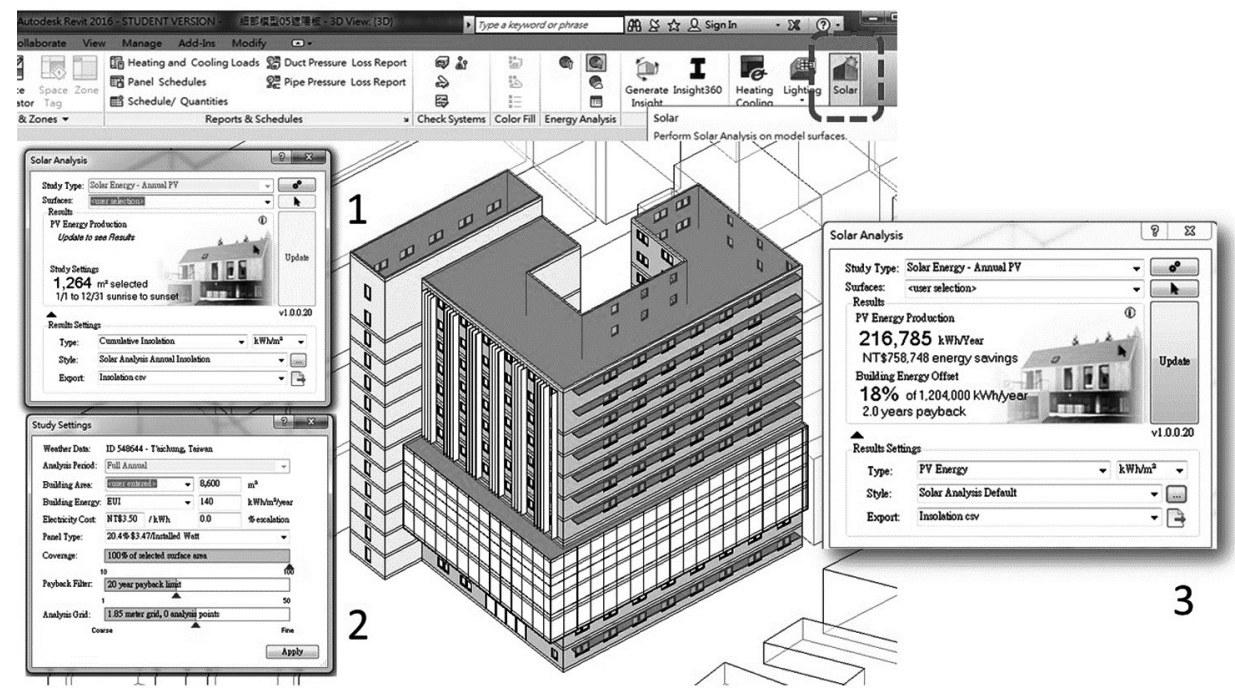

Figure 19. Results of Solar Analysis command implementation 
or off-site renewable energy can be obtained through the power grid. Apart from solar panels, we hope that Software vendor will gradually add other renewable energy modules in the future to facilitate relevant simulations.

\section{Conclusions}

Following the common NZEB framework, based on various considerations, different participants can draft NZEB projects suitable for their countries. This article concludes as follows:

1) After reviewing the current situation in Taiwan, this study emphasizes that only operating stage power consumption should be considered in NZEB design. An NZEB must be an energy-efficient building, and its wholebuilding energy consumption can be offset by renewable energy generated on-site or obtained nearby so that a balance is achieved between energy consumption and energy output.

2) The energy consumption calculations in this study used EUI, which chiefly considers electricity, as a unit, and we recommend that optimized energy performance is used for performance targets and grading criteria. This study employed average values, which are from the Comparative Table of Power Consumption per Unit Area for Different Types of Building Users issued by the Bureau of Energy, Ministry of Economic Affairs, as referenced common baseline values.

3) Taking a new-construction hotel in Taichung as an example, this study verified the applicability of BIM-Revit software's built-in Energy Analysis and Solar Analysis modules. Designers can use Green BIM as NZEB's integrated design and analysis decision-making tool to continually improve the design to meet "net zero" performance objectives.

4) Although green BIM's assessment and scoring methods are very objective and scientific, the validity of its performance simulations is frequently questioned. The application of green BIM can not only enable the prediction of EUI values and analysis of energy efficiency during the design planning stage but can also facilitate continued tracking and analysis of changes in the EUI value by the Bureau of Energy after the building is completed and in use. Long-term data collection has enabled the comparison of predicted values obtained using green BIM with the actual values after projects are in use, which has provided feedback to specialists and facilitated the revision of the hypotheses used in this energy simulation software. As the futurist Stewart Brand observed, "Each building has a prediction, and each prediction is wrong. However, as time passes the error in these predictions will gradually decrease, especially predictions concerning high-performance buildings" (Crawley, Pless, \& Torcellini, 2009).

\section{Acknowledgements}

This work was supported by the Ministry of Science and Technology project: Using Neural Network Supervised
Learning to Enhance Green BIM-based Optimization, Taking the adaptive lighting environment as an example, under Grant [MOST 106-2221-E-035-039-].

\section{References}

Andrasik, P. (2015). Building performance analytics: establishing a methodology of design integration. Journal of the National Institute of Building Science, 3(4), 28-30.

Annual Electrical Power Consumption by Building Occupants per Unit Area. (2015). Energy Bureau of the Ministry of Economic Affairs. Retrieved from http://www.ecct.org.tw/ReadFile/?p=Knowledge $\& n=4 c c e c 70 a-8 a 69-43 f 5-b 9 d 4-3274271$ bd182.pdf

Ascione, F., Bianco, N., Böttcher, O., Kaltenbrunner, R., \& Vanoli, G. P. (2016). Net-zero-energy buildings in Germany: design, model calibration, and lessons learned from a case-study in Berlin. Energy and Buildings, 133, 688-710.

https://doi.org/10.1016/j.enbuild.2016.10.019

BREEAM. (2017). Retrieved from http://www.breeam.com/

Building Energy Software Tools. (2017). US Dept. of Energy. Retrieved from http://www.buildingenergysoftwaretools.com/

CASBEE. (2017). Institute for Building Environment and Energy Conversation. Retrieved from http://www.ibec.or.jp/CASBEE/

Crawley, D., Pless, S., \& Torcellini, P. (2009). Getting to Net Zero, National Renewable Energy Laboratory (NREL). U.S. Department of Energy. http://www.nrel.gov/docs/fy09osti/46382.pdf

Deng, S., Wang, Z., \& Dai, Y. J. (2014). How to evaluate the performance of net-zero energy building - a literature research. Energy, 71, 1-16. https://doi.org/10.1016/j.energy.2014.05.007

Desideri, U., Arcioni, L., Leonardi, D., Cesaretti, L., Perugini, P., Agabitini, E., \& Evangelisti, N. (2014). Design of a multi-purpose "zero energy consumption" building according to European Directive 2010/31/EU: life cycle assessment. Energy and Buildings, 80, 585-597.

https://doi.org/10.1016/j.enbuild.2014.05.027

Eastman, C. M. (2008). BIM Handbook: a guide to building information modeling for owners, managers, designers, engineers, and contractors. John Wiley \& Sons, Inc.

https://doi.org/10.1002/9780470261309

EEWH. (2017). Taiwan Architecture \& Building Center. Retrieved from http://gb.tabc.org.tw/modules/news/article.php?storyid $=5$

Eleftheriadis, S., Mumovic, D., \& Greening, P. (2017). Life cycle energy efficiency in building structures: a review of current developments and future outlooks based on BIM capabilities. Renewable and Sustainable Energy Reviews, 67, 811-825. https://doi.org/10.1016/j.rser.2016.09.028

Emilekfouri. (2013). Green Building Studio and Standard 140. Autodesk. Retrieved from http://blogs.autodesk.com/insight/ green-building-studio-and-standard-140/

European Commission. (2017). Nearly zero-energy buildings. Retrieved from https://ec.europa.eu/energy/en/topics/energy-efficiency/buildings/nearly-zero-energy-buildings

GB: Assessment standard for Green Building. (2014). Ministry of Housing and Urban-Rural Development of the People's Republic of China. Retrieved from http://baike.baidu.com/item/\% E7\%BB\%BF\%E8\%89\%B2\%E5\%BB\%BA\%E7\%AD\%91\%E8\% AF\%84\%E4\%BB\%B7\%E6\%A0\%87\%E5\%87\%86/241182

Green Building Studio. (2017). Building Performance Analysis Raised to the Power of the Cloud, Autodesk ${ }^{\circledR}$. Retrieved from https://gbs.autodesk.com/GBS/

Green Star. (2017). Green Building Council Austria. Retrieved from http://new.gbca.org.au/green-star/ 
Gurgun, A. P., Polat, G., Damci, A., \& Bayhan, H. G. (2016). Performance of LEED energy credit requirements in European countries. Procedia Engineering, 164, 432-438.

https://doi.org/10.1016/j.proeng.2016.11.641

Intelligent building. (2017). Taiwan Architecture \& Building Center. Retrieved from http://ib.tabc.org.tw/

Jalaei, F., \& Jrade, A. (2015). Integrating building information modeling (BIM) and LEED system at the conceptual design stage of sustainable buildings. Sustainable Cities and Society, 18, 95-107. https://doi.org/10.1016/j.scs.2015.06.007

Japan Zero Energy Buildings. (2017). House Energy. Retrieved from http://www.house-energy.com/NZEB/Japan-ZNEB.html

LEED. (2017). U.S. Green Building Council. Retrieved from https://www.usgbc.org/leed

LEED: Energy and Atmosphere (EA) category. (2017). U.S. Green Building Council. Retrieved from https://www.usgbc. org/credits/new-construction/v4/energy-\%26-atmosphere

LEED: Optimize energy performance. (2017). U.S. Green Building Council. Retrieved from https://www.usgbc.org/ node/2614273?return=/credits/new-construction/v4/energy-\%26amp\%3B-atmosphere

Maile, T., Fischer, M., \& Bazjanac, V. (2007). Building energy performance simulation tools - a life-cycle and interoperable perspective. Stanford University. Retrieved from http://citeseerx. ist.psu.edu/viewdoc/download?doi=10.1.1.486.4124\&rep=rep $1 \&$ type $=$ pdf

Malkin, S. (2008). Meteorological data for Building Energy Analysis. Autodesk $k^{\oplus}$. Retrieved from http://sustainabilityworkshop.autodesk.com/sites/default/files/core-page-files/weather_data_greenbuildingstudio_adsk_white_paper.pdf

Marszal, A. J., Heiselberg, P., Bourrelle, J. S., Musall, E., Voss, K., Sartori, I., \& Napolitano, A. (2011). Zero Energy Building - a review of definitions and calculation methodologies. Energy and Buildings, 43, 971-979.

https://doi.org/10.1016/j.enbuild.2010.12.022
Mohamed, A., Cao, S., Hasan, A., \& Sirén, K. (2014). Selection of micro-cogeneration for net-zero energy buildings (NZEB) using weighted energy matching index. Energy and Buildings, 80, 490-503. https://doi.org/10.1016/j.enbuild.2014.05.055

NetZero Energy Commercial Building Initiative. (2017). U.S. Department of Energy. Retrieved from https://www1.eere. energy.gov/buildings/publications/pdfs/alliances/cbi_fs.pdf

Østergård, T., Jensen, R. L., \& Maagaardb, S. E. (2016). Building simulations supporting decision making in early design - a review. Renewable, and Sustainable Energy Reviews, 61, 187201. https://doi.org/10.1016/j.rser.2016.03.045

Ryu, H. S., Park, K. S., \& Rosen, M. R. (2016). A Study on the LEED Energy Simulation Process Using BIM. Sustainability, 8(2), 1-13. https://doi.org/10.3390/su8020138

Sartori, I., Napolitano, A., \& Voss, K. (2012). Net zero energy buildings: a consistent definition framework. Energy and Buildings, 48, 220-232. https://doi.org/10.1016/j.enbuild.2012.01.032

Shrestha, P. (2016). Lords reject government decision to scrap zero carbon homes. In Energy Live News. Retrieved from http://www.energylivenews.com/2016/04/28/lords-reject-government-decision-to-scrap-zero-carbon-homes/

Task 40. (2017). Net Zero Energy Solar Buildings. Retrieved from http://task40.iea-shc.org/

Torcellini, P., Pless, S., \& Deru, M. (2006). Zero energy buildings: a critical look at the definition. National Renewable Energy Laboratory. Retrieved from http://www.nrel.gov/docs/fy06osti/39833.pdf

Xie, H. Z. (2011). The Zero Energy Building Technology Alliance (ZEBTA) established conference report. In Energy reports. Retrieved from http://www.zebta.org.tw/pdf/ZEBTA\%20 Cover\%20story\%20201108.pdf 